УДК 339

О. Г. Мельник,

д. е.н., професор, завідувач кафедри зовнішньоекономічної та митної діяльності,

Начіональний університет "

M. E. Адамів,

к. е.н., дочент кафедри зовнішньоекономічної та митної діяльності,

Начіональний університет " $ь$ вівська політехніка", м. Аьвів

A. В. Тодошук,

к. е. н., дочент кафедри зовнішньоекономічної та митної діяльності,

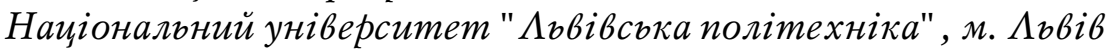

DOI: $10.32702 / 2306-6814.2018 .20 .5$

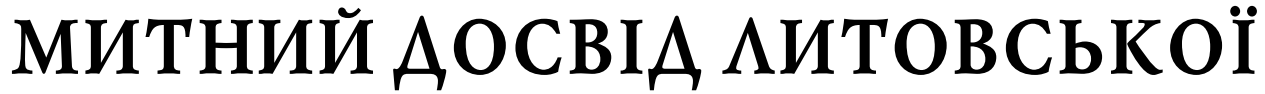

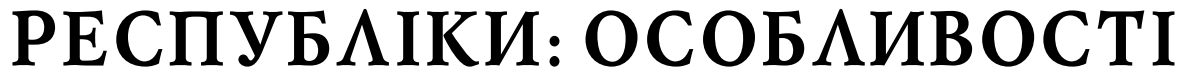 IMП $\Lambda$ МЕНТАЦIÏ В УКРАЇНI ${ }^{1}$
}

\author{
O. Melnyk, \\ Doctor of Economic Sciences, Professor, Head of Department of Foreign Economic \\ and Customs Activity, Lviv Polytechnic National University, Lviv \\ M. Adamiv, \\ Doctor of Philosophy in Economics, Associate Professor of Department of Foreign Economic \\ and Customs Activity, Lviv Polytechnic National University, Lviv \\ A. Todoshchuk, \\ Doctor of Philosophy in Economics, Associate Professor of Department of Foreign Economic \\ and Customs Activity, Lviv Polytechnic National University, Lviv
}

\section{CUSTOMS EXPERIENCE OF THE REPUBLIC OF LITHUANIA: PECULIARITIES OF IMPLEMENTATION IN UKRAINE}

У статті обгрунтовано актуальність реформування митної системи України на засадах врахування зарубіжного досвіду побудови та функціонування митних систем в умовах європейської інтеграції. Доведено репрезентативність досвіду роботи митних органів Литовської Республіки у контексті удосконалення та розвитку вітчизняної митної системи. Виконано порівняльну характеристику результатів роботи митних органів Литви та України за митними позиціями у провідних міжнародних рейтингах. Комплексно проаналізовано особливості Функціонування литовської митної системи в контексті організаційної побудови митних органів, стратегічного планування діяльності, міжнародного співробітництва. На основі одержаних результатів ідентифіковано ключові тенденції роботи митних органів Литви, що визначають успішність литовської митниці та її гармонізованість із європейськими митними принципами. Розроблено цільові рекомендації щодо реформування митної системи України з пріоритетним та обгрунтованим урахуванням принципів роботи литовської митниці.

At the present stage, Ukrainian customs system is in a stagnant phase, which is characterized by the existence of a significant number of objective and subjective problems that should be solved by the joint efforts of representatives of the authorities through the effective reforming the customs activities. In the conditions of European integration of Ukraine, the solution of this complex task is seen through the study of the successful experience of representative European states regarding the construction and functioning of their customs systems that are based on the use of European customs principles and operate effectively on the European and international levels. Based on the

${ }^{1}$ Публікація містить результати досліджень, проведених за грантової підтримки Держаного фонду фундаментальних досліджень за конкурсним проектом Ф83/81-2018. 
consideration of a number of parameters and peculiarities of the development of different European countries, the Republic of Lithuania was selected as one of the representative countries whose customs experience can be adequately used in reforming the customs system of Ukraine. Based on the comparative analysis of the results of the work of the customs authorities of Lithuania and Ukraine by customs positions in the leading international ratings, significant inequality was found in the levels of development of the Lithuanian and Ukrainian customs systems. The peculiarities of the functioning of the Lithuanian customs system in the context of the organizational construction of customs bodies, strategic planning, and international cooperation are analyzed in detail. On the basis of the obtained results, the key trends of the work of the Lithuanian customs authorities are identified, which determine the success of the Lithuanian customs and its harmonization with European customs principles. The targeted recommendations for reforming the customs system of Ukraine with the priority and reasoned consideration of the principles of the Lithuanian customs work are developed. All of these recommendations are united by the conceptual idea of distinguishing an independent customs authority - the National Customs Service, which would separately operate along with fiscal and treasury services under the jurisdiction of the Ministry of Finance of Ukraine. The implementation of this idea will provide a clear and logically justifiable demarcation of fiscal and customs spheres, allow to focus on realization and strengthening core customs functions, and perform key customs assignment which is primarily connected with the comprehensive assistance to legal and fair international trade, the fight against illegal foreign economic operations, national security, and the protection of society.

Ключові слова: митна система, митні органи, митний досвід, рефформування, Литовська Республіка, Україна, європейська інтеграція.

Key words: customs system, customs authorities, customs experience, reforming, the Republic of Lithuania, Ukraine, European integration.

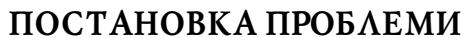

Сучасний етап розвитку України характеризується доволі контроверсійними тенденціями, що, з однієї сторони, відображають перспективні можливості європейської інтеграції, а з іншої сторони, репрезентують соціальноекономічну та військово-політичну нестабільність у державі. За таких обставин зусилля представників різних сорер та різних рівнів повинні бути спрямовані на виведення національної економіки із кризового стану та забезпечення її прогресивного розвитку у структурі європейської економіки. У вирішенні цього завдання ключову роль відіграє митна система держави, що іманентно покликана виконувати важливі для країни фрункції, пов'язані, насамперед, із забезпеченням національної безпеки держави, ії̈ територіальної цілісності, захистом суспільства від небезпечних неякісних та заборонених товарів, фрормуванням економічної конкурентоспроможності та інвестиційної привабливості на різних рівнях тощо. Для митних органів розвинених європейських держав така практика є усталеною, що дозволяє досягнути високих показників соціально-економічного розвитку країни та сорормувати позитивний імідж держави у структурі Європейського Союзу (ЄС). На жаль, кардинально інша ситуація простежується у роботі вітчизняних митних органів, що відображає стагнаційний етап розвитку національної митної системи, її недієздатність якісно виконувати безпекову, захисну та митну функції. Такий стан справ спричинений існуванням чималої кількості різноманітних проблем об'єктивного та суб'єктивного характеру, котрі повинні бути ефективно та оперативно вирішені на засадах цілеспрямовано ресрормування вітчизняної митної системи. При цьому для виконання означеного завдання в умовах прагнень України доєднатись до $Є С$ недостатньо опиратись лише на власний попередній митний досвід, адже історія розвитку вітчизняних митних органів не репрезентує кращу митну практику. Таким чином, виникає необхідність у дослідженні досвіду найбільш репрезентативних по відношенню до України європейських держав, що зуміли сфрормувати ефективно фрункціонуючі митні системи.

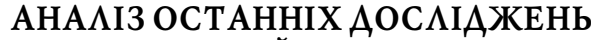

ТА ПУБАІКАЦІЙ

На сучасному етапі до складу ЄС входить 28 держав, при цьому ЄС почав функціонувати у 1951 р. як спільнота, що об'єднала Бельгію, Німеччину, Францію, Італію, Люксембург та Нідерланди. Впродовж свого існування та функціонування ЄС активно розвивався, інтегруючи нові країни. На сьогодні чимало європейських держав перебувають на різних етапах приєднання до структури ЄС. Так, ключовими кандидатами-країнами, котрі гармонізують національне та європейське законодавство, $є$ Албанія, Монтенегро, Сербія, Колишня Республіка Югославії Македонія, Туреччина [1]. За таких обставин виникає необхідність у визначенні найбільш істотних параметрів вибору репрезентативної європейської держави для дослідження її митного досвіду та його подальшого можливого проектування на вітчизняну митну практику. 3 огляду на вищевикладений сучасний стан і тенденції розвитку України, історію її становлення як незалежної держави, військово-політичний конфлікт з Росією, а також ключові проблеми у роботі вітчизняних митих органів вибір здійснено на користь Литовської Республіки.

Литовська Республіка (Литва) - це держава, що розташована на півночі Європи, $є$ однією із трьох країн Балтії, межує із Латвійською Республікою, Білоруссю, Росією та Польщею, омивається Балтійським морем. Загальна площа території складає 65301 кв. км., у 2017 р. чисельність населення становила 2,836 млн ос. [2]. Як і Україна, Литва 
входила до складу СРСР, проте вже у 2004 р. стала членом ЄС. Не зважаючи на значно меншу площу території Литви та чисельність її населення порівняно із Україною, репрезентативність вивчення досвіду побудови, становлення та розвитку литовської митної системи обгрунтовується перебуванням Литви, як і України, у структурі СРСР, межуванням із Російською Федерацією та спроможністю на цьому фоні приєднатись до ЄС і забезпечити значно вищий рівень розвитку держави, ніж в Україні. Усе вищевикладене підтверджує показовість митного досвіду Литви для України у контексті, по-перше, побудови митної системи за європейським взірцем та, по-друге, забезпечення національної безпеки держави, її територіальної цілісності та провадження законної торгівлі в умовах межування із Росією.

\section{ЦІ I АОС IАЖЕНHЯ}

Зважаючи на усе вищевикладене, цілями подальшого дослідження $є$ вивчення досвіду побудови та розвитку митних органів Литви, ідентифікування найбільш адекватних до сучасного стану вітчизняної митної системи особливостей митної діяльності у Литві та фрормування на цій основі обгрунтованих рекомендацій щодо реформування митної сорери України.

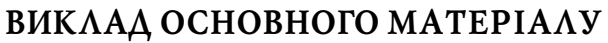 АОСАІАЖЕННЯ}

Насамперед, проаналізуємо позиції Литовської Республіки у ключових міжнародних рейтингах, що характеризують роботу митних органів держави. Відповідно до даних Міжнародного рейтингу "Doing Business" [3] у 2018 р. Литва посідала 19 місце у числі 190 країн світу за параметром "Міжнародна торгівля". Так, для проходження прикордонного та митного контролю у Литві при реалізації експортних операцій знадобиться в середньому 9 год. та 58 дол. США, тоді як у країнах ОЕСР з високим рівнем доходу - 12,7 год. та 149,9 дол. США відповідно. Офрормлення пакету документів при експорті в Литві триває близько 3 год. та вартує 28 дол. США, а у країнах ОЕСР - 2,4 год. та 35,4 дол. США відповідно. Своєю чергою, часові і вартісні показники щодо проходження прикордонного та митного контролю при здійсненні імпортних операцій у Литві, а також вартість оформлення документації при імпорті дорівнюють нулю, а оформлення пакету документів при імпорті займає приблизно 1 год. У країнах ОЕСР з високим рівнем доходу для проходження прикордонного та митного контролю при здійсненні імпортних операцій необхідно в середньому 8,7 год. та 111,6 дол. США, а для оформлення документації при імпорті знадобиться 3,5 год. та 25,6 дол. США. Як бачимо, більшість розглянутих вище показників у Литовській Республіці, що характеризують експортні операції, приблизно відповідають аналогічним середнім показникам у країнах ОЕСР з високим рівнем доходу або ж перевищують їх, тоді як імпортні показники у досліджуваній країні істотно перевищують середні показники країн ОЕСР та відображають кращу практику. Порівнюючи вищенаведені показники Литви та України, слід зауважити про існування істотного розриву в усіх сферах, що вказує на значно нижчий рівень розвитку національної митної системи та наявність критичних проблем, котрі провокують такий стан справ та повинні бути вирішенні за допомогою реалізації прогресивних ефективних та дієвих реформ.

Згідно із Індексом ефективності логістики [4], котрий формується Світовим Банком, у 2018 р. за параметром "Митниця" Литва займала 46 позицію серед 159 держав світу, тоді як Україна знаходилась на 88 місці. За даними Індексу сприяння торгівлі [5], що складається Світовим
Економічним Форумом та Глобальним Альянсом, у 2016 р. досліджувана країна посідала 29 місце серед 139 держав, а Україна перебувала лише на 95 сходинці рейтингу. Таким чином, простежуємо істотну нерівність у рівнях розвитку литовської та української митних систем і за даними інших рейтингів.

Нижче більш ретельно проаналізуємо особливості побудови та фрнкціонування митних органів Литви.

У Литві центральним митним органом $є$ митним підрозділ (Центральна митна служба) у структурі Міністерства фрінансів Литовської Республіки, Головою якого $\epsilon$ виконуючий обов'язки Генерального директора Йонас Міскініс. Як бачимо, за типом митної адміністрації Центральна митна службає відокремленим самостійним підрозділом Міністерства. За даними 2018 р. литовська митниця налічувала близько 2110 ос. Організаційно митна система Литви охоплює Центральну митну службу, Митну кримінальну службу, Центр підготовки митних працівників, Митну лабораторію, Центр митно-інформаційної системи, три територіальні митні служби (у м. Вільнюсі, Каунасі та Клайпеді) та 44 митних пости [6].

Робота митних органів Литви реалізовується відповідно до Стратегії розвитку литовської митниці на 20162020 рр. Місія литовської митниці полягає у забезпеченні законної, безпечної, чесної та безперебійної міжнародної торгівлі у державі. Метою роботи митних органів Литви $€$ забезпечення надійного захисту суспільства, ринку, навколишнього середовища та фінансових інтересів Литовської Республіки та ЄС у сорері міжнародної торгівлі, імплементації митної політики ЄС, спільної торгівлі та інших спільних політик Союзу, пов'язаних із міжнародною торгівлею. У своїй роботі митні органи Литви орієнтуються та такі цінності, як: повага до кожної особи (фрізичної та юридичної) і держави; профресіоналізм; партнерство. При цьому довгострокові стратегічні цілі литовської митниці пов'язані із забезпеченням належної та оптимальної для клієнтів реалізації митних процедур, посиленням боротьби із нечесною та незаконною міжнародною торгівлею, злочинністю та загрозами національній і міжнародній безпеці, розширенням інституційних компетенцій митних органів. Слід зауважити, що кожна довгострокова ціль конкретизується у переліки конкретних завдань. Оцінювання рівня досягнення стратегічних цілей литовської митниці здійснюється відповідно до таких критеріїв [6]:

- $100 \%$ - забезпечення відповідальності митниці Литви щодо своєчасного та якісного виконання проектів, зазначених у робочій програмі Митного кодексу ЄС на 2020 р.;

- $60 \%$ - зростання довіри до митниці Литви у 2020 р. (44\% - y 2015 p.);

- $15 \%$ - зниження проценту незаконного ввезення тютюнових виробів у загальній частці ринку Литви у 2020 р. (19,6 \% - у IV кварталі 2015 р.);

- 3 \% - підвищення рівня мотивації персоналу Литовської митниці кожні два роки порівняно з результатами попереднього опитування.

Варто зазначити, що стратегія розвитку литовської митниці реалізовується шляхом розроблення довгострокового плану дій щодо імплементації стратегії, його щорічного перегляду та оцінки досягнутого прогресу; складання річних бізнес-планів та цільових планів дій, а також контролювання за їх виконанням; ініціювання та реалізації проектів розвитку бізнесу та електронної митниці; вдосконалення системи управління якістю роботи литовської митниці, розширення сорери акредитації для митної лабораторії, забезпечення безпеки IT-систем, що використовуються митницею; цільового використання людських ресурсів, інформаційних ресурсів та державних фрондів 3 максимальною ефективністю [6]. 
При здійсненні контролю за міжнародною торгівлею в межах ЄС, митниця Литви сприяє забезпеченню чесної та відкритої торгівлі, захисту внутрішнього ринку Литовської Республіки, безпеки усього ланцюга постачання. У тісній співпраці з іншими органами влади митні органи Литви відіграють ключову роль у забезпеченні законної торгівлі та зміцненні конкурентоспроможності держави $€ C$; належного оподаткування зовнішньоекономічної діяльності; боротьбі з різними видами шахрайства, організованою злочинністю, незаконним переміщенням наркотичних речовин та тероризмом шляхом якісного оброблення інформації, ідентифікування змін у моделях торгівлі та оцінювання ризиків для виявлення фрінансових шахрайств, терористичних і злочинних дій; захисті навколишнього середовища танаселення від усіх видів небезпечної продукції [6].

Доцільно також зауважити, що литовська митниця веде активну міжнародну діяльність на засадах митної співпраці із ЄС та міжнародними організаціями, успішної реалізації численних міжнародних та регіональних митних програм проектів, а також надання технічної підтримки з митних питань іншим державам. У контексті реформування вітчизняної митної системи варто згадати про проект ЄС Twinning в Україні "Підтримка Державної фріскальної служби України щодо зміцнення елементів інтегрованого управління кордонами у митній сфері", котрий з січня 2016 р. литовська митниця у співпраці з німецькими та польськими митними органами реалізовує впродовж 21 місяця. Бюджет проекту складає 1800000 євро. Загальна мета проекту полягає у формуванні засад ефективного митного управління та цілісності в Україні на основі принципів інтегрованого управління кордонами. Команда міжнародних експертів реалізовує цю проектну діяльність у таких сферах: внесення змін до законодавства, що стосуються інтегрованого управління кордонами, оперативні механізми співпраці в межах інтегрованого управління кордонами, розвиток антикорупційної системи. Ключовим партнером проекту $\epsilon$ Федеральне міністерство фрінансів Німеччини (відповідає за першу вищезазначену сореру), а також Міністерство фрінансів Польщі (відповідає за другу сферу) та литовська митниця (відповідає за третю сореру) [6].

Окрім того, у 2016 р. представники митних органів Литви провели спеціалізовані семінари для працівників Державної фріскальної служби України у сорері нагляду та контролю за діяльністю митних брокерів, митного постаудиту та управління тарифнними квотами. У 2017 р. для працівників Державної фріскальної служби України було організовано 2 навчальних візити у митницю Литви щодо використання платіжних систем на пунктах пропуску, а також визначення походження товарів. Також представники литовської митниці організували спеціалізований семінар в м. Києві з питань запобігання, виявлення та розслідування митних правопорушень та практичної імплементації загальноєвропейської і середземноморської конвенції про правила походження товарів. Литовська митниця бере участь у Місії ЄС з прикордонної допомоги в Україні та Молдові (EUBAM) [6].

Ретельно проаналізувавши роботу митних органів Литви та оперуючи отриманими вищевикладеними результатами дослідження, можна виокремити такі ключові особливості функціонування литовської митної системи, що визначають ії̈ успішність, гармонізованість із європейськими митними принципами та можуть бути враховані під час реформування митних органів в Україні:

- ефективна організаційна побудова митних органів Литви, що репрезентована виокремленням незалежного самостійного митного органу влади у структурі Міністерства фрінансів і таким чином забезпечує чітке й логічно об- грунтоване розмежування фріскальної та митної сфрер, дає змогу зосередитись на реалізації ключових митних функцій, їхньому розвитку та удосконаленні. За даними Всесвітньої митної організації [7] така практика побудови митних органів $\epsilon$ домінуючою у світі;

- чітка митно-орієнтована стратегія розвитку литовської митної системи, ключові елементи якої стосуються властивого митниці функціонального призначення, пов'язаного, насамперед, із всебічним сприянням законній та чесній міжнародній торгівлі, боротьбою із нелегальними зовнішньоекономічними операціями, забезпеченням національної та міжнародної безпеки;

- перманентний динамічний розвиток митної системи Литви, що грунтується на впровадженні прогресивних митних технологій та інструментів задля підвищення рівня автоматизованості митних процесів, удосконаленні митної інфрраструктури, розвитку мотиваційних та навчальних механізмів тощо;

- активний розвиток Інституту уповноваженого економічного оператора на засадах об'єктивного удосконалення системи спрощень для суб'єктів господарювання, заохочення підприємницьких структур до одержання цього статусу та його пропагування у бізнес-середовищі;

- перманентне вдосконалення системи управління митними ризиками, її інформаційно-аналітичної складової у контексті співпраці з іншими національними та міжнародними контролюючими органами з метою оперативної реалізації заходів протидії митним порушенням;

- поєднання принципів комплексності та вибірковості митного контролю на усіх етапах ланцюга постачання, що дозволяє підвищити рівень виявлення митних правопорушень та водночас пришвидшити реалізацію митних процедур;

- удосконалення механізмів оперативно-розшукової діяльності митних працівників, що знижує ймовірність потрапляння на ринок країни та ЄС небезпечних, шкідливих чи якісних товарів;

- жорсткий контроль та чітке й об'єктивне звітування митних працівників щодо цільовості використання залучених фрінансових ресурсів під час реалізації різноманітних митних програм та проектів, що формує позитивний імідж митних органів Литви як надійного сумлінного партнера в очах європейських донорів та створює передумови для подальшої ефективної співпраці;

- активна міжнародна діяльність митних органів Литви, що, насамперед, забезпечує репрезентацію та врахування митних інтересів Литовської Республіки у європейському законодавстві, здобуття нового успішного досвіду щодо впровадження прогресивних митних інструментів, одержання цільової фрінансової допомоги ЄС для реалізації внутрішніх митних проектів, налагодження взаємовигідної співпраці із новими партнерами, тощо.

Усі вищеокремлені особливості фрункціонування митних органів Литви можна логічним чином врахувати при реформуванні вітчизняної митної системи, що зумовило формування низки пропозицій у цій сфрері:

- обгрунтована реорганізація митної системи України на засадах виокремлення самостійного й незалежного митного органу - Національної митної служби, котра б відокремлено функціонувала поряд із податковою та казначейською службами у підпорядкуванні Міністерства орінансів України, що забезпечуватиме логічно обгрунтоване виокремлення, зміцнення та розвиток митних функцій держави;

- розроблення чіткої митно-орієнтованої стратегії розвитку митної системи України, котра органічно компонуватиме ключові невід'ємні стратегічні елементи, що стосуватимуться, передусім, виконанням властивих цьому 
органу влади функцій - безпекової, захисної та митної, тоді як фріскальна фрункція повинна розглядатись як похідна фрункція від зазначених основних функцій;

- виконання положень Митного кодексу України [8] щодо запровадження та фрункціонування Інституту уповноваженого економічного оператора в державі для заохочення сумлінних та законослухняних підприємств до ведення зовнішньоекономічної діяльності і таким чином активізації міжнародної торгівлі;

- активізація розвитку митної системи України на засадах масштабного удосконалення митної інфрраструктури та програмно-технічного забезпечення роботи митних органів, підвищення рівня автоматизованості митних процесів, підвищення рівня мотивованості та компетентності митних працівників, що знижуватиме рівень корупції та підвищуватиме якість реалізації митних операцій, тощо;

- удосконалення роботи Автоматизованої системи аналізу та управління ризиками, фрормування єдиної інфрормаційно-аналітичної системи, котра об'єднуватиме інформацію вітчизняних митних органів з даними різних правоохоронних органів (Служби безпеки України, Національної поліції України, Державної прикордонної служби України, судовими органами тощо), а також іноземних митних органів задля оперативного виявлення правопорушень та вжиття відповідних заходів протидії;

- забезпечення здійснення митного контролю на усіх етапах ланцюга постачання, запровадження механізму митного пост-аудиту з метою підвищення рівня виявлення митних правопорушень та пришвидшення реалізації митних процедур;

- надання митним працівникам права на здійснення оперативно-розшукової діяльності на усій території України, удосконалення способів забезпечення виконання штрафних санкцій правопорушниками, що підвищуватиме рівень виявлення митних злочинів та посилюватиме відповідальність заїхнє здійснення;

- забезпечення цільовості використання залучених фрінансових ресурсів під час реалізації різноманітних митних програм та проектів на засадах запровадження жорсткого контролю у цій сорері та посилення механізмів відповідальності;

- активізація міжнародної діяльності вітчизняних митних органів шляхом співробітництва із міжнародними організаціями та зарубіжними митними органами, участі у різноманітних міжнародних програмах та проектах, Торгових місіях, тощо з метою залучення цільової фінансової допомоги, одержання рекомендацій з удосконалення вітчизняної митної системи, представлення національних митних інтересів на міжнародному рівні тощо.

\section{ВИСНОВКИ ТА ПЕРСПЕКТИВИ АОСАІАЖЕНЬ}

На сучасному етапі митна система України перебуває на етапі стагнації, характеризується існуванням чималої кількості об'єктивних та суб'єктивних проблем, що мають бути вирішені спільними зусиллями представників органів влади у різних сорерах шляхом масштабного ефективного реформування роботи митних органів. Вумовах європейської інтеграції України вирішення цього комплексного завдання вбачається через вивчення успішного досвіду репрезентативних європейських держав щодо побудови та функціонування митних систем, які грунтуються на використанні європейських митних принципів та ефективно функціонують на європейському та міжнародному рівнях. На підставі врахування низки параметрів та особливостей розвитку різних європейських держав обрано Литовську Республіку як одну із репрезентативних країн, митний досвід якої може бути адекватно використаний при реформуванні митної системи України. Таким чином було ретель- но досліджено особливості фрункціонування митних органів Литви та ідентифіковано ключові тенденції їхньої роботи, що визначають успішність литовської митниці та її гармонізованість із європейськими митними стандартами, правилами та принципами. На основі одержаних результатів логічно розроблено цільові рекомендації щодо реформування митної системи України з пріоритетним та обгрунтованим урахуванням принципів роботи литовської митниці.

Перспективами подальших досліджень $є$ поглиблене аналізування вітчизняного митного досвіду з метою ідентифрікування ключових нагальних проблем у цій сфрері, що повинні бути вирішені на засадах розроблення й впровадження ефективних реформаторських заходів.

Література:

1. Офріційний сайт Європейського Союзу [Електронний ресурс]. - Режим доступу: https://europa.eu/europeanunion/about-eu/countries_en

2. Офріційний сайт Департаменту статистики Литовської Республіки [Електронний ресурс]. - Режим доступу: http://www.std.lt/

3. Офіційний сайт Міжнародного рейтингу Світового банку "Doing Business" [Електронний ресурс]. - Режим доступу: http://www.doingbusiness.org /

4. Звіт Світового Економічного Форуму та Глобального Альянсу "The Global Enabling Trade Report 2016" [Електронний ресурс]. - Режим доступу: http:// reports.weforum.org/global-enabling-trade-report-2016/ \# topic $=$ data

5. Офіційний сайт Міжнародного рейтингу Світового банку "Logistics Performance Index" [Електронний ресурс]. - Режим доступу: https://Ipi.worldbank.org/

6. Офіційний сайт митниці Литовської Республіки [Електронний ресурс]. - Режим доступу: http://www.Irmuitine.It

7. Офріційний сайт Всесвітньої митної організації [Електронний ресурс]. - Режим доступу: www.wcoomd.org/

8. Митний кодекс України № 4495-VI від 13.03.2012 p. [Електронний ресурс]. - Режим доступу: http:// zakon.rada.gov.ua/laws/show/4495-17

References:

1. The official site of the European Union (2018), available at: https: / / europa.eu /european-union/about-eu /countries en (Accessed 12 September 2018).

2. The official site of the Department of Statistics of the Republic of Lithuania, available at: http://www.std.It/ (Accessed 12 September 2018).

3. The official site of the International Rating of the World Bank "Doing Business" (2018), available at: http:// www.doingbusiness.org/ (Accessed 10 August 2018).

4. World Economic Forum and the Global Alliance (2017), "The Global Enabling Trade Report 2016", available at: http:/ /reports.weforum.org/global-enabling-trade-report-2016/ \#topic=data (Accessed 10 August 2018).

5. The official site of the International Rating of the World Bank "Logistics Performance Index" (2018), available at: https://Ipi.worldbank.org/(Accessed 10 August 2018).

6 . The official site of Customs of the Republic of Lithuania (2018), available at: http://www.Irmuitine.It (Accessed 15 September 2018).

7. The official site of the World Customs Organization (2018), available at: www.wcoomd.org/ (Accessed 20 August 2018).

8. The Verkhovna Rada of Ukraine (2012), "The Customs Code of Ukraine", available at: http: / /zakon.rada.gov.ua/ laws /show /4495-17 (Accessed 7 September 2018). Стаття надійшла до редакиї 26.09.2018 p. 